\title{
The Role of Asset Management, Operational Efficiency and Expense Management on the Performance of Commercial Banks in Bangladesh
}

\author{
A. N. M. Minhajul Haque Chowdhury ${ }^{1}$, Rafia Akhtar ${ }^{2}$
}

${ }^{1}$ MBA, Department of Finance and Banking, Hajee Mohammad Danesh Science and Technology University, Dinajpur-5200, BANGLADESH

${ }^{2}$ Associate Professor, Department of Finance and Banking, Hajee Mohammad Danesh Science and Technology University, Dinajpur-5200, BANGLADESH

*E-mail for correspondence: mhchowdhury2016@gmail.com

https://doi.org/10.18034/abr.v7i3.16

\begin{abstract}
The performance of the banks depends on some bank-specific factors. This paper set out to investigate the influence of asset management, operational efficiency and expense management on the financial performance of five commercial banks in Bangladesh for the period of 2011-2015. Descriptive statistics, correlation, and regression techniques were applied to find out the ultimate results. The empirical study suggested that operational efficiency had a positive effect on the dependent variables return on asset (ROA), and return on equity (ROE), but expense management was negatively related to the both indicators. On the other hand, asset management was positively related to ROA but negatively related to ROE. In addition, the regression results summed up that the changes in the performance of commercial banks could explain by bank-specific factors selected for the study.
\end{abstract}

Key words: Return on equity, return on asset, asset management, commercial Banks, operational efficiency, expense management

\section{JEL Classification Code: G 21}

\section{INTRODUCTION}

Performance of the banks is the indicator of financial soundness of the economy. If the banks of a country have a positive return and the growth of performance is consisting, then it can be said that the country is developing in economic aspects. In the paper, the concerning elements are assets, Operating income, operating expenses, net interest income, ROA, and ROE. The study shows that operational efficiency, asset management, and expense management are sufficient to explain the changes in the profit indicators of the banks.

\section{Objective of the Study}

This study intends to identify the effect of operating income and expenses on the total asset as well as the operational efficiency of commercial banks in Bangladesh.

\section{LITERATURE REVIEWS}

Rose and Hudgins (2005) stated that earlier the managers of the banking industry particularly focused on the tool of asset management that is they put more importance on the selection and control of the asset.

Shah and Jan (2014) conducted a study on Pakistani private banks with the purpose to analyze the financial performance of the banks. The most powerful tool for the study was correlation and regression analysis. Returns on asset and interest income were the dependent variables whereas size of the bank, asset management and operational efficiency considered as independent variables. By analyzing top ten private commercial banks the researchers found that asset management had a positive impact on ROA but operational efficiency and bank size were negatively related with ROA.

Karim and Alam (2013) investigated five private commercial banks in Bangladesh in order to measure the performance of selected banks for the period 2008-2012. The regression results of the study claimed that size of the bank, credit risk, operational efficiency and asset management had a significant effect on the performance of the commercial banks in Bangladesh. 
Ayadi and Ellouze (2015) studied on the performance of the banks in Tunisia during 2003-2012. In their study return on asset was the dependent variable whereas quality of asset, capitalization, net interest income, non- interest income, size of the banks, inflation, ownership structure, and revolution were the independent variables. The results of the study revealed that asset quality, traditional activities, nontraditional activities and inflation had no effect on the performance of Tunisian banks. On the other hand capitalization had a positive impact on the ROA of the banks.

Samad (2015) examined the impact of bank specific and macroeconomic factors on the profitability of 42 commercial banks in Bangladesh. The findings of the study stated that liquidity risk, credit risk, operational efficiency and capital efficiency had a significant influence on profitability but bank size, economic growth and inflation had no such effect on the profitability of the banks in Bangladesh over the period 2009-2011.

Alkhatib and Harsheh (2012) conducted a study on the financial performance of the banks in Palestine over the period of 2005-2010.the performance indicator of the study were return on asset, Tobin's Q model and economic value added. They used correlation and regression analysis as statistical tools to conclude. Their findings from the study concluded that bank size, credit risk, operational efficiency, and asset management had a significant impact on the financial performance of the five selected commercial banks listed on Palestine Securities Exchange (PEX).

Onuonga S. M. (2014) analyzed the profitability of the commercial banks in Kenya on the basis of internal factors. His study suggested that capital strength, ownership, bank size and operational expenses had a significant effect on the profitability of the banks.

Uddin and Bristy (2014) studied on five private commercial banks in Bangladesh to find out the growth pattern and trend line of employees, branches, deposits, loans, profit after tax and earnings per share. This study revealed that the growth and trend of the variables were constantly growing and that indicated private banking private banking can be very promising in Bangladesh.

\section{Research Methodology and Design}

To conduct the study the researchers select five commercial banks of Bangladesh which are AB Bank Limited, Dhaka Bank Limited, Eastern Bank Limited, Mercantile Bank Limited and Premier Bank Limited. Financial data was collected from the annual reports of these banks for the period of 2011-2015. Ratio analysis, descriptive statistics (mean, median, minimum, maximum, and standard deviation), correlation, and regression analysis were the main statistical tools of these study. This Study comprises the independent variables Operating Income to Total Asset Ratio (OITA), Net Interest Income to Operating Expenses Ratio (NIIOE) and Operating Expenses to Total Asset Ratio (OETA). Return on Assets (ROA) and Return on Equity (ROE) are dependent variables. The equations are given below:

1. Operating Income to Total Asset Ratio,

$$
\text { OITA }=\frac{\text { Total Operating Income }}{\text { Total Asset }}
$$

2. Net Interest Income to Operating Expense Ratio,

$$
\mathrm{NIIOE}=\frac{\text { Net interest income }}{\text { Operating Expenses }}
$$

(Net interest income $=$ Interest Income - Interest Expenses)

3. Operating Expense to Total Asset Ratio,

$$
\begin{gathered}
\text { OETA }=\frac{\text { Total Operating Expenses }}{\text { Total Asset }} \\
\text { 4. Return on Asset, ROA }=\frac{\text { Profit after Tax }}{\text { Average Total Asset }} \\
\text { 5. Return on Equity, ROE }=\frac{\text { Profit after Tax }}{\text { Average Total Equity }}
\end{gathered}
$$

The regression analysis constitutes two models - model 1 and model 2. The regression equations for both models are as follows:

\section{Model 1:}

$\mathrm{ROA}=\beta_{0}+\beta_{1}$ OITA $+\beta_{2} \mathrm{NIIOE}+\beta_{3} \mathrm{OETA}+\varepsilon_{\mathrm{it}}$

Model 2:

$\mathrm{ROE}=\beta_{0}+\beta_{1}$ OITA $+\beta_{2}$ NIIOE $+\beta_{3}$ OETA $+\varepsilon_{i t}$

Where,

$\beta_{0}$ : Represents the intercept.

$\beta_{1}, \beta_{2}, \beta_{3}$ : Represents the coefficients of regression relations.

$\varepsilon_{\mathrm{it}}:$ Represents error term

Hypothesis for model 1:

$\mathrm{H}_{0}$ : There is no relationship among ROA, OITA, NIIOE and OETA.

$\mathrm{H}_{1}$ : There is a relationship among ROA, OITA, NIIOE and OETA.

Hypothesis for model 2:

$\mathrm{H}_{0}$ : There is no relationship among ROE, OITA, NIIOE and OETA.

$\mathrm{H}_{1}$ : There is a relationship among ROE, OITA, NIIOE and OETA.

\section{RESULTS AND ANALYSIS}

Ratio analysis (OITA, NIIOE, OETA, ROA and ROE) for the five selected commercial banks during 2011-2015 is presented in table 1 . Table 2, 3, 4, 5 and 6 presented the descriptive statistics of the ratios of $\mathrm{AB}$ Bank Limited, Dhaka Bank Limited, Eastern Bank Limited, Mercantile Bank Limited, and Premier Bank Limited respectively. 
Table 1: Ratio analysis of the banks

\begin{tabular}{|c|c|c|c|c|c|c|}
\hline $\begin{array}{l}\text { Name of } \\
\text { the Bank }\end{array}$ & Year & OITA & NIIOE & OETA & ROA & ROE \\
\hline \multirow{5}{*}{$\begin{array}{c}\text { AB Bank } \\
\text { Ltd }\end{array}$} & 2011 & 0.0561 & 0.8929 & 0.0241 & 0.0096 & 0.0953 \\
\hline & 2012 & 0.0513 & 0.8863 & 0.0244 & 0.0088 & 0.0936 \\
\hline & 2013 & 0.0482 & 0.8923 & 0.0218 & 0.0057 & 0.0655 \\
\hline & 2014 & 0.0514 & 1.1950 & 0.0217 & 0.0065 & 0.0807 \\
\hline & 2015 & .0386 & 0.8087 & 0.0199 & 0.0054 & 0.0670 \\
\hline \multirow{5}{*}{$\begin{array}{c}\text { Dhaka } \\
\text { Bank Ltd }\end{array}$} & 2011 & 0610 & 1.2237 & 0.0186 & 0.0229 & 0.2825 \\
\hline & 2012 & 0.0420 & 1.2713 & 0.0163 & 0.0066 & 0.0826 \\
\hline & 2013 & 0.0459 & 1.2068 & 0.0191 & 0.0142 & 0.1815 \\
\hline & 2014 & 0.0454 & 0.9185 & 0.0195 & 0.0137 & 0.1677 \\
\hline & & & & & & \\
\hline \multirow{5}{*}{$\begin{array}{l}\text { Eastern } \\
\text { Bank Ltd }\end{array}$} & 2011 & 0.0672 & 1.2347 & 0.0232 & 0.0255 & 0.1901 \\
\hline & 2012 & 0.0599 & 1.4765 & 0.0225 & 0.0180 & 0.1502 \\
\hline & 2013 & 0.0605 & 1.3200 & 0.0237 & 0.0166 & 0.1415 \\
\hline & 2014 & 0.0594 & 1.0097 & 0.0256 & 0.0128 & 0.1102 \\
\hline & 2015 & 0.0542 & 0.7353 & 0.0262 & 0.0125 & 0.1115 \\
\hline \multirow{5}{*}{$\begin{array}{l}\text { Mercantile } \\
\text { Bank Ltd }\end{array}$} & 2011 & 0.0528 & 0.6590 & 0.0226 & 0.0172 & 0.2075 \\
\hline & 2012 & 0.0406 & 0.6860 & 0.0187 & 0.0101 & 0.1322 \\
\hline & 2013 & 0.0514 & 0.5159 & 0.0216 & 0.0132 & 0.1674 \\
\hline & 2014 & 0.0477 & 0.7020 & 0.0216 & 0.0145 & 0.1742 \\
\hline & 2015 & 0.0437 & 0.6174 & 0.0222 & 0.0150 & 0.1827 \\
\hline \multirow{5}{*}{$\begin{array}{l}\text { Premier } \\
\text { Bank Ltd }\end{array}$} & 2011 & 0.0576 & 0.4954 & 0.0467 & 0.0071 & 0.0789 \\
\hline & 2012 & 0.0476 & 0.5674 & 0.0375 & 0.0077 & 0.0873 \\
\hline & 2013 & 0.0493 & 0.5423 & 0.0323 & 0.0091 & 0.1038 \\
\hline & 2014 & 0.0462 & 0.5769 & 0.0299 & 0.0095 & 0.1135 \\
\hline & 2015 & 0.0416 & 0.6708 & 0.0266 & 0.0079 & 0.1002 \\
\hline
\end{tabular}

Source: Authors

From table 2 it is observed that $A B$ Bank Limited had minimum OITA, NIIOE, OETA and ROA in 2015. The highest OITA, ROA and ROE of this bank came in 2011. The maximum variation of results of $A B$ Bank Limited was of NIIOE as its SD was $14.96 \%$. In table 3 Dhaka Bank Limited had minimum OETA, ROA and ROE in 2012 and minimum OITA, ROA and ROE in 2015. This bank experienced the highest OITA, ROA and ROE in 2011 whereas the SD of NIIOE was the maximum during that period. Eastern Bank Limited had minimum OITA, NIIOE and ROA in 2015, minimum OETA in 2012 and minimum ROE in 2014 as showed in table 4. The highest ROA and ROE of Eastern Bank Limited came in 2011 and this bank had the lowest variation of OETA for that period. Table 5 states that the lowest ROA of $1.02 \%$ and ROE of $13.23 \%$ experienced by Mercantile Bank Limited in 2012. Table 6 shows that Premier Bank Limited had 0.83\% mean value of ROA and $9.68 \%$ mean value of ROE. The maximum OITA and OETA came in 2011 whereas the maximum ROA and ROE of this bank came in 2014.

Table 2: Descriptive statistics of AB Bank Ltd

\begin{tabular}{|c|c|c|c|c|c|}
\hline Ratios & $\mathrm{N}$ & Min. & Max. & Mean & SD \\
\hline OITA & 5 & 0.0387 & 0.0561 & 0.049184 & 0.0065167 \\
\hline NIIOE & 5 & 0.8088 & 1.1950 & 0.935074 & 0.1495843 \\
\hline OETA & 5 & 0.0199 & 0.0245 & 0.022421 & 0.0018852 \\
\hline ROA & 5 & 0.0054 & 0.0097 & 0.007244 & 0.0019033 \\
\hline ROE & 5 & 0.0656 & 0.0954 & 0.080472 & 0.0141193 \\
\hline
\end{tabular}

Table 3: Descriptive statistics of Dhaka Bank Ltd

\begin{tabular}{|c|c|c|c|c|c|}
\hline Ratios & $\mathrm{N}$ & Min. & Max. & Mean & SD \\
\hline OITA & 5 & .0395 & .0610 & .046764 & .0083829 \\
\hline NIIOE & 5 & .6174 & 1.2714 & 1.047575 & .2775806 \\
\hline OETA & 5 & .0163 & .0195 & .018424 & .0012478 \\
\hline ROA & 5 & .0066 & .0230 & .013305 & .0062886 \\
\hline ROE & 5 & .0827 & .2826 & .165599 & .0767065 \\
\hline
\end{tabular}

Table 4: Descriptive statistics of Eastern Bank Ltd

\begin{tabular}{|c|c|c|c|c|c|}
\hline Ratios & $\mathrm{N}$ & Min. & Max. & Mean & SD \\
\hline OITA & 5 & .0542 & .0673 & .060306 & .0046440 \\
\hline NIIOE & 5 & .7354 & 1.4766 & 1.155305 & .2890595 \\
\hline OETA & 5 & .0225 & .0262 & .024272 & .0016037 \\
\hline ROA & 5 & .0125 & .0255 & .017125 & .0052584 \\
\hline ROE & 5 & .1102 & .1901 & .140746 & .0328532 \\
\hline
\end{tabular}

Table 5: Descriptive statistics of Mercantile Bank Ltd

\begin{tabular}{|c|c|c|c|c|c|}
\hline Ratios & $\mathrm{N}$ & Min. & Max. & Mean & SD \\
\hline OITA & 5 & 0.0406 & 0.0529 & 0.047306 & 0.0051378 \\
\hline NIIOE & 5 & 0.5160 & 0.7020 & 0.636095 & 0.0743980 \\
\hline OETA & 5 & 0.0187 & 0.0226 & 0.021377 & 0.0015286 \\
\hline ROA & 5 & 0.0102 & 0.0172 & 0.014058 & 0.0026013 \\
\hline ROE & 5 & 0.1323 & 0.2076 & 0.172859 & 0.0273032 \\
\hline
\end{tabular}

Table 6: Descriptive statistics of Premier Bank Ltd

\begin{tabular}{|c|c|c|c|c|c|}
\hline Ratios & $\mathrm{N}$ & Min. & Max. & Mean & SD \\
\hline OITA & 5 & .0416 & .0577 & .048523 & .0058735 \\
\hline NIIOE & 5 & .4955 & .6708 & .570617 & .0642938 \\
\hline OETA & 5 & .0266 & .0468 & .034680 & .0078614 \\
\hline ROA & 5 & .0071 & .0095 & .008290 & .0010176 \\
\hline ROE & 5 & .0789 & .1136 & .096772 & .0137253 \\
\hline
\end{tabular}

Table 7: Descriptive statistics of all the banks (2011-15)

\begin{tabular}{|c|c|c|c|c|c|}
\hline & OITA & NIIOE & OETA & ROA & ROE \\
\hline Mean & .050417 & .86893 & .024235 & .012004 & .131290 \\
\hline Median & .048523 & .935074 & .022421 & .013305 & .140746 \\
\hline SD & .005611 & .255687 & .006211 & .004141 & .041135 \\
\hline Min. & .0468 & .5706 & .0184 & .0072 & .0805 \\
\hline Max. & .0603 & 1.1553 & .0347 & .0171 & .1729 \\
\hline
\end{tabular}

The descriptive statistics of all the selected banks are illustrated in table 7. Asset management which was indicated by OITA was most efficient of Eastern Bank Limited but Dhaka Bank Ltd had the lowest OITA of 0.0468 among the selected banks. Eastern Bank Ltd had also the highest operational efficiency as it had highest NIIOE of 1.16 but Premier Bank Limited had the lowest operational efficiency during that period. On the other hand Premier Bank Limited was most efficient in managing the expenses. Dhaka Bank Limited had the lowest OETA and this is the reason why6 this bank was least efficient in expense management. ROA and ROE were lowest of AB Bank Limited whereas Eastern Bank Limited had the highest ROA and Mercantile Bank Limited had the highest ROE.

The correlation matrix of OITA, NIIOE, OETA, ROA, and $\mathrm{ROE}$ is presented in table 8 . It can be observed from the table that ROA had a positive correlation with OITA and NIIOE but a negative correlation with OETA whereas ROE had a positive correlation with NIIOE but a negative correlation with OITA and OETA. 
Table 8: Pearson correlation

\begin{tabular}{|l|l|c|c|c|c|c|}
\hline & & OITA & NIIOE & OETA & ROA & ROE \\
\hline \multirow{4}{*}{ OITA } & Pearson Correlation & 1 & 0.590 & 0.093 & 0.564 & -0.036 \\
\cline { 2 - 7 } & Sig. (2-tailed) & & 0.295 & 0.882 & 0.322 & 0.954 \\
\cline { 2 - 7 } & $\mathrm{N}$ & 5 & 5 & 5 & 5 & 5 \\
\hline \multirow{3}{*}{ NIIOE } & Pearson Correlation & 0.590 & 1 & -0.566 & 0.476 & 0.145 \\
\cline { 2 - 8 } & Sig. (2-tailed) & 0.295 & & 0.320 & 0.418 & 0.816 \\
\cline { 2 - 7 } & $\mathrm{N}$ & 5 & 5 & 5 & 5 & 5 \\
\hline \multirow{3}{*}{ OETA } & Pearson Correlation & 0.093 & -0.566 & 1 & -0.422 & -0.574 \\
\cline { 2 - 7 } & Sig. (2-tailed) & 0.882 & 0.320 & & 0.479 & 0.312 \\
\cline { 2 - 7 } & $\mathrm{N}$ & 5 & 5 & 5 & 5 & 5 \\
\hline \multirow{3}{*}{ ROE } & Pearson Correlation & 0.564 & 0.476 & -0.422 & 1 & 0.805 \\
\cline { 2 - 7 } & Sig. (2-tailed) & 0.322 & 0.418 & 0.479 & & 0.100 \\
\cline { 2 - 7 } & $\mathrm{N}$ & 5 & 5 & 5 & 5 & 5 \\
\cline { 2 - 7 } & Pearson Correlation & -0.036 & 0.145 & -0.574 & 0.805 & 1 \\
\cline { 2 - 7 } & Sig. (2-tailed) & 0.954 & 0.816 & 0.312 & 0.100 & \\
\cline { 2 - 7 } & $\mathrm{N}$ & 5 & 5 & 5 & 5 & 5 \\
\hline
\end{tabular}

There was a negative correlation between OETA and NIIOE. At the same time OITA had a positive relation with NIIOE and OETA.

Table 9: Regression analysis of Model 1

\begin{tabular}{|c|c|c|c|c|c|c|c|}
\hline & \multicolumn{7}{|c|}{ Model 1 (ROA as dependent variable) } \\
\hline & \multicolumn{2}{|c|}{$\begin{array}{c}\text { Unstandardized } \\
\text { Coefficients }\end{array}$} & \multirow{2}{*}{$\begin{array}{c}\begin{array}{c}\text { Standardized } \\
\text { Coefficients }\end{array} \\
\text { Beta }\end{array}$} & \multirow[t]{2}{*}{$\mathrm{t}$} & \multirow[t]{2}{*}{ Sig. } & \multicolumn{2}{|c|}{$\begin{array}{c}\text { Collinearity } \\
\text { Statistics }\end{array}$} \\
\hline & $\mathrm{B}$ & Std. Error & & & & Tolerance & Beta \\
\hline Constant & -.003 & .024 & & -.120 & .924 & & \\
\hline OITA & .731 & .720 & .990 & 1.015 & .495 & .383 & 2.611 \\
\hline NIIOE & -.010 & 019 & -.588 & -.499 & .705 & .262 & 3.811 \\
\hline OETA & -.565 & .637 & -.847 & -.887 & .538 & .399 & 2.505 \\
\hline $\mathrm{R}$ & \multicolumn{7}{|c|}{.797} \\
\hline $\mathrm{R}^{2}$ & \multicolumn{7}{|c|}{.636} \\
\hline Adjusted $\mathrm{R}^{2}$ & \multicolumn{7}{|c|}{-.458} \\
\hline
\end{tabular}

Table 10: Regression analysis of Model 2

\begin{tabular}{|c|c|c|c|c|c|c|c|}
\hline \multirow{2}{*}{} & \multicolumn{7}{|c|}{ Model 2 (ROE as dependent variable) } \\
\cline { 2 - 9 } & $\begin{array}{c}\text { Unstandardized } \\
\text { Coefficients }\end{array}$ & $\begin{array}{l}\text { Standardized } \\
\text { Coefficients }\end{array}$ & $\mathrm{t}$ & Sig. & $\begin{array}{c}\text { Collinearity } \\
\text { Statistics }\end{array}$ \\
\cline { 2 - 9 } & $\mathrm{B}$ & Std. Error & Beta & & & Tolerance & Beta \\
\hline Constant & .218 & .286 & & .761 & .586 & & \\
\hline OITA & 3.593 & 8.636 & .490 & .416 & .749 & .383 & 2.611 \\
\hline NIIOE & -.117 & .229 & -.729 & -.512 & .699 & .262 & 3.811 \\
\hline OETA & -6.833 & 7.640 & -1.032 & -.894 & .535 & .399 & 2.505 \\
\hline $\mathrm{R}$ & \multicolumn{7}{|c|}{.685} \\
\hline $\mathrm{R}^{2}$ & \multicolumn{7}{|c|}{.469} \\
\hline Adjusted $\mathrm{R}^{2}$ & \multicolumn{7}{|c|}{-1.125} \\
\hline
\end{tabular}

The correlation matrix of OITA, NIIOE, OETA, ROA, and ROE is presented in table 8 . It can be observed from the table that ROA had a positive correlation with OITA and NIIOE but a negative correlation with OETA whereas ROE had a positive correlation with NIIOE but a negative correlation with OITA and OETA. There was a negative correlation between OETA and NIIOE. At the same time OITA had a positive relation with NIIOE and OETA.

The regression results for model 1 and model 2 are represented in table 9 and table 10 respectively. For model 1 , the $\mathrm{R}^{2}$ was $64 \%$. This indicates that the independent variables (asset management, operational efficiency and expense management) could explain the changes in the dependent variable ROA by $64 \%$. For model 2 there was a $\mathrm{R}^{2}$ of $50 \%$ and it indicates that the independent variables of the study were able to explain the changes in dependent variable ROE. So, the null hypotheses for both models were rejected.

\section{CONCLUSION}

The financial performance of the banks is a consequence of some internal and external factors. This study attempts to find out the effects of some internal factors those have significant influence on banks performance. Using secondary data from the financial statements of the five selected commercial banks the researchers preceded the study. The correlation results indicated that asset management (OITA) positively affect the ROA but have negative influence on ROE. The results also showed the evidence that operational efficiency (NIIOE) had a positive effect but expense management (OETA) had a negative effect on the performance indicator of the study. The regression test provides the information that the independent variables (OITA, NIIOE and OETA) could explain the changes in ROA by $64 \%$ and ROE by $50 \%$.

\section{ACKNOWLEDGEMENT}

The authors wish to thank their parents as well as all the very honorable teachers who always inspire in making an aim for better future.

\section{REFERENCES}

Alkhatib A. \& Harsheh M. (2012). "Financial performance of Palestinian commercial banks," International Journal of Business and Social Science, vol. 3, no. 3, pp. 175-184.

Ayadi I. \& Ellouze A. (2015). "The determinants of the Tunisian banking performance: A panel data analysis," International Journal of Economics and Finance, vol. 7, no. 1, pp. 262-272.

Chowdhury, A., Siddiqua, A., \& Chowdhury, A. (2016). Relationship between Liquidity Risk and Net Interest Margin of Conventional Banks in Bangladesh. Asian Business Review, 6(3), 175-178.

Karim R. A. \& Alam T. (2013). "An evaluation of financial performance on private commercial banks in Bangladesh: Ratio analysis," Journal of Business Studies Quarterly, vol. 5, no. 2, pp. 65-77.

Onuonga S. M. (2014). "The analysis of profitability of Kenya's top six banks: internal factor analysis," American International Journal of Social Science, vol. 3, no. 5, pp. 94-103.

Rose P. S. \& Hudgins S. C. (2005). "Bank Management and Financial Services," Sixth Edition. McGraw Hill Education, pp.195-233.

Samad A. (2015). “Determinants bank profitability: Empirical evidence from Bangladesh commercial banks," International Journal of Financial Research, vol. 6, no 3, pp. 173-179.

Shah S. Q. \& Jan R. (2014). "Analysis of financial performance of private banks in Pakistan," Procedia-Social and Behavioral Sciences. 109: 1021-1025.

Siddiqua, A., Chowdhury, A., Chowdhury, A., Mainuddin, M., \& Rahman, M. (2017). Impact of Internal Factors on the Profitability of Banks: A Case of Commercial Banks in Bangladesh. Asian Business Review, 7(1), 7-14.

Uddin M. R. \& Bristy J. F. (2014). “Evaluation of some private commercial banks in Bangladesh from performance perspective," International Journal of Managing Value and Supply Chains, vol. 5, no.4, pp. 1-17.

$$
--0--
$$

